\title{
STRATEGIC GOALS FOR POST-INDUSTRIAL CITIES \\ BASED ON THE EXAMPLE OF THE ZABRZE CITY DEVELOPMENT STRATEGY
}

\author{
Dariusz KRAWCZYK \\ Municipal Office in Zabrze [Urząd Miejski w Zabrzu]; d.krawczyk@olpress.pl, ORCID: 0000-0003-1823-0309
}

Purpose: Effective social and economic revitalisation of post-industrial cities involves municipal government entities undertaking planning activities. The aim of the paper is to analyze these activities as the entities have to set not only far-reaching goals to be achieved, but also develop a strategy to achieve the intended results, which acts as a basis for the selection of optimal tactical actions. The city planning document needs to refer to broader regional, metropolitan and national strategies and include specific sectoral programmes within the city. In addition, it should include an evaluation model that ensures the verification of the effectiveness of the operations undertaken.

Methodology: The Zabrze development strategy was analysed to determine the content of planning documents in the field of development strategy of post-industrial cities. The content of the document, taking into account the specified priorities, was then verified with systematically prepared reports specifying the degree of implementation of plans, budgetary outlays and the schedule of activities.

Findings: As a result, it was possible to link the planning assumptions with the facts in the case of the revitalisation of the city, which, several years ago, was a centre of heavy industry with numerous mines, steelworks and manufacturing plants. We focused primarily on the analysis of the implementation of tasks related to social and infrastructure revitalisation. It was agreed that in the case of Zabrze, the development of a new field of economic activity, i.e. post-industrial heritage tourism, played an important role.

Value: It has been shown that consistent implementation of the adopted plans by the local government can result in a change of the image of the city.

Keywords: development strategy, strategic planning, municipal government, post-industrial areas, revitalisation.

\section{Introduction}

The aim of the article is to present the role of planning documents in the execution of the organisation's development strategy. It highlights the importance of proper selection of priorities and the setting of far-reaching challenges to be achieved in such a way as to 
adequately allocate resources. During the analysis of the assumptions of the programmes prepared in Zabrze, the determinants of the development of the post-industrial city have been specified. The advantage, as well as the burden, of Zabrze is its concentration of industrial heritage objects. Hence, the method of structuring the plans, the implementation formula of the adopted assumptions and the method of verifying the level of their execution were carefully presented. The mechanisms of stimulating new forms of social, economic, cultural, educational and tourist activity in the post-industrial city were outlined, as well as the synergy effect in the form of inclusion of commercial entities in revitalisation programmes conducted by the municipal government authorities.

\section{The significance of planning documents in the management of the organisation}

Carefully prepared planning documents are a factor that fundamentally influences management effectiveness and also conditions the organisation's development opportunities. The documents facilitate the proper conduct of organisational, coordination, execution and evaluation activities. They help to organise the rules of perception of events and occurrences within and around a given entity. These documents shape the ability to make the proper decisions in order to achieve far-reaching goals of activity and mission execution, understood as the essence of the organisation's existence. Owing to this, they facilitate the introduction of a strategic management model that optimises the functioning not only of economic institutions, but also of social, political and administrative organs. One of the model examples is the country. It is possible to indicate a few selected documents which provide direction to changes in the economic, social and political reality in Poland. Historically, the development of the country was to be determined by strategies such as the plan to create a Central Industrial District [Centralny Okręg Przemysłowy], because "the construction of the COP was to spread across all territories of Poland and integrate individual areas of the partition. It was undoubtedly an important element of the idea of harmonising the legal and economic system of the Second Polish Republic. The announcement of the 4-year investment plan in 1936 had a direct connection with the construction of the Central Industrial District. The investment planning was to include the entire country" (Chudzik, 2014, p. 26). After the end of World War II, during the period of the Polish People's Republic [PRL], the strategy of industrialisation was implemented. The "centralised command-based planning and management system adopted together with it, although it was unable to ensure an increase in factor productivity and economic efficiency, was an effective instrument in the hands of economic and political authorities. It was a powerful instrument in mobilising the workforce and ensuring full employment, as well as achieving a high rate of accumulation and concentration of resources on a number of selected targets" 
(Leśkiewicz, Sienicka, 1982, p. 165). In 1989, the process of political transformation was initiated. Alongside the turbulent social and economic transformations, this period was also related to a reflection on the definition of planning procedures. The creator of such programmes as "Strategy for Poland", "Package 2000" or "Programme for the Repair of Finance of the Republic of Poland" emphasised that "the idea of an appropriate strategy for Poland originated over a period of many years, although the Strategy for Poland itself - a multi-year, multifaceted programme of dynamic social and economic development, based on the construction of social market economy institutions and structural reforms responding to the challenges of globalisation - was created quickly, at the turn of 1993 and 1994. From a political point of view, it was a medium-term programme, which referred in detail to the measures necessary in the years 1994-1997, although it also defined many tasks for later years" (Kołodko, 2019, p. 66). It is also possible to mention the "National Development Strategy (NDS) for 2007-2015", which is a document adopted by the Council of Ministers on 29 November 2006, and "Poland - 2025. A long-term strategy for the sustainable and balanced development of Poland in the perspective of the year 2025", stating that "such economic development includes the protection of the natural environment and human resources, taking into consideration the long-term perspective, as the vital components of social welfare" (Siekierski, 2013, p. 152).

However, the resolution of the Council of Ministers of 25 September 2012 adopted the "Country 2020 Development Strategy: Active Society, Competitive Economy, Efficient Country", and the "update of the country's mid-term development strategy" is the "Strategy for Responsible Development by 2020 (with the perspective by 2030)", currently in force in Poland, adopted by the Council of Ministers on 14 February 2017, which "sovereignly defines the strategic vision of Poland's development, principles, goals and development priorities in four dimensions: economic, social, spatial and environmental, by 2020 (with the perspective by 2030). It also modifies all the previous strategic decisions concerning the development of Poland. The main objective currently is to create conditions for increasing the income and wealth of the inhabitants of Poland, and thus increase cohesion in the social, economic, territorial and environmental dimensions" (Prusek, 2019, pp. 183-184). The planning document, setting out the strategic and tactical objectives to be accomplished within a set time period and using the tools to achieve them, creates the basic framework for the current activity of the country's structures. It also determines the directions that should be taken into consideration by the acts concerning lower levels of public administration, such as regional development plans and strategies of cities and municipalities. 


\section{The contents of the city development strategy on the example of the document "Zabrze Strategy 2030"}

There are some municipal government entities in which "perfectly organised systems of strategic planning and management function, using not only mandatory but also optional management tools" (Potkański, 2016, p. 337), but this is still not a common situation. Meanwhile, the development strategy is a fundamental study referring to the future of the city. It contains long-term plans and defines the manner of achieving the set goals. Preceded by social consultations and workshops, "Zabrze Development Strategy 2030"1, adopted in 2018 on the basis of the city's characteristics, formulates a strategic balance sheet of Zabrze using the method of analysis of internal (strengths and weaknesses) and external (opportunities and threats) factors. These factors were arranged in a socio-cultural, economic-technological and infrastructural-environmental system. The conclusions reached allowed for a formulation of a vision of the city, understood as a far-reaching goal to be achieved, in the following wording: "Zabrze is a city creating its development based on the aspiration of: popularisation and consolidation of active social attitudes and conscious participation in contemporary cultural processes, creation of competitive specialisations of various industries, including innovative economy, creation of friendly urban spaces and achievement of a significant position in the Metropolitan Association of Upper Silesia and Dąbrowa Basin." ${ }^{2}$ The next element was to determine development priorities. These were identified as follows: "P1. Active urban society, P2. Development and innovativeness of the economy, P3. Friendliness of the urban space, P4. Significant metropolitan position" ${ }^{3}$. According to the authors of the document, the priority: "Active urban society" strives to support persuasive actions aimed at directing the inhabitants to the desired behaviour. It involves consistent popularisation of attitudes of conscious participation in the life of the city. The goals are to improve the social situation of the poorest, stop young people leaving the city, increase the level of the educational, cultural, sports and recreational offer or attract new inhabitants to the city. The priority emphasises the aspiration to overcome the passivity of many social groups, which increases the claimability, inheritance of social pathologies and weakens cultural attachment to the local community, resulting in greater propensity for migration. The priority is accompanied by a strategic challenge "To actively participate in social development".

The second priority, "Development and innovativeness of the economy", defines the economic orientation of development of Zabrze, integrating the aspirations of the city authorities and entrepreneurs on positive changes in the existing state of companies,

\footnotetext{
${ }^{1}$ Zabrze Development Strategy 2030 was adopted by the City Council on 27 August 2018. The document was a result of the work of a team of scientists led by Adam Drobniak from the University of Economics in Katowice: Marcin Baron, Małgorzata Czornik, Piotr Gibas.

${ }^{2}$ Defining the vision of Zabrze development until 2030. Zabrze City Development Strategy 2030, p. 27.

${ }^{3}$ Priority list. Zabrze City Development Strategy 2030, p. 28.
} 
the technologies used to manufacture products, the range of the urban market or the modernity of the offer. This priority presents the will to achieve leadership in creating a climate favourable to entrepreneurship and investments - understood in a comprehensive manner that is also taking into account, for example, the educational profile of schools. According to the authors, by choosing such a priority, Zabrze is in line with the pan-European trend of striving to maintain the investment attractiveness and good position of European Union countries in the global competition for a modern customer. This priority is accompanied by a strategic challenge "Strengthening the economic competitiveness of the city".

The third priority, "Friendliness of the urban space", emphasises emotional considerations in the assessment of the spatial order by the inhabitants. The authors of the study accentuate that Zabrze wishes the city residents to associate it with positive images and contribute to the enrichment of its set of advantages. Therefore, the space should be well perceived and serve the inhabitants to satisfy their numerous needs. In this way, a sense of satisfaction is to be created. It is formed by, among others, equipment and facilities, as well as orderly forms of spatial development. Consistent implementation of the assumptions of spatial order will help to determine clear maps of the location of urban functions and avoid spatial conflicts. This priority is accompanied by a strategic challenge - "Domesticating space in the city".

The fourth priority, "Significant metropolitan position", shows a desire to strengthen the position of Zabrze in the Metropolitan Association of Upper Silesia and Dąbrowa Basin. Zabrze wants to guarantee its participation in making important decisions concerning the sub-regional policy of the Silesian Voivodeship. As the authors of the document affirm: the city, which has a significant population potential and a central location, effectively competes for a metropolitan client with tourist products or medical services but wants to expand its economic and cultural offer. The essence of this priority is to create a unique Zabrze offer and then strengthen the position of the city in the metropolitan market of post-industrial heritage tourism and medical services, as well as increase the international recognition of the city in the field of culture and sport and build to the rank of an important centre of higher education and science. This priority is accompanied by a strategic challenge — "To stand out in the Metropolitan Association of Upper Silesian and Dąbrowa Basin".

The authors of the study wrote that "the formulation of visions and priorities for development enables the move to the next level of strategic reflection, oriented towards the identification of objectives, i.e. intentional states and aspirations indicating the desired effects of the city development resulting from the implementation of the strategy"4 with a distinction between strategic objectives, directly related to a specific priority and horizontal objectives, in other words, related to all priorities. The established priorities were further assigned directions of development based on selected activities and projects specifying them in detail. This stage already links strategic planning with operational planning.

\footnotetext{
${ }^{4}$ Strategic and horizontal objectives. Zabrze City Development Strategy 2030, p. 30.
} 
A part of the study was also the description of conformity in the field of binding strategy documents of a higher order. A correlation was made at the level of goals, comparing them with the key provisions of the country and regional documents, including: "The long-term development strategy of the country. Poland 2030", "Strategy for sustainable development", "National Spatial Planning Concept 2030", "National Urban Policy 2023", "Strategy for the Development of Southern Poland in the Lesser Poland and Silesian Voivodeships by 2020", "Silesian Voivodeship Development Strategy ŚLĄSKIE 2020+", "ZIT Strategy of the Central Sub-Region of the Silesian Voivodeship for the years 2014-2020"5 and "Sustainable Urban Mobility Plan of the Central Sub-Region of the Silesian Voivodeship".

The discussed strategy was introduced in 2018 after the implementation of the assumptions of the previously binding document "Zabrze City Development Strategy for 2008-2020" . The document also included "an axiological analysis, a strategic analysis in terms of strengths and weaknesses of the city, as well as opportunities and threats, a SWOT analysis with strategic recommendations, vision and development priorities, strategic objectives and horizontal objectives" ${ }^{7}$. The stages of its implementation were evidenced based on reporting and collecting data necessary for strategic management, as monitoring "opportunities or threats in the vicinity of the city that may significantly modify the existing assumptions concerning the desired future" is also crucial ${ }^{8}$.

\subsection{Verification of the level of implementation of the city development strategy}

The degree of fulfilment of planning documents in Zabrze was assessed by means of a cyclical preparation based on source data (from departments of the City Hall in Zabrze, from municipal organisational units and other institutions) - the so-called "City Status Reports", the primary objective of which was to present indicators characterising the "positive and negative sides of processes in the described areas of city life" ${ }^{\prime 9}$. These reports included, among others, the general characteristics of the city (including its historical overview, symbols, signs, geographical location, specification of its supporting entities) and detailed data relating to local government management (decision-making and executive board), the city's population, spatial management, construction, transport and communication, environmental protection and quality of the environment. The indicators concerning water and sewage management, waste, as well

\footnotetext{
${ }^{5}$ This concerns Integrated Territorial Investments [ZIT - Zintegrowane Inwestycje Terytorialne]. They constitute a tool that enables financing from the European Regional Development Fund (ERDF) and the European Social Fund (ESF) of partnership initiatives between local government units of cities and areas functionally related to them.

${ }^{6}$ Zabrze City Development Strategy for the years 2008-2020 was adopted as Annex No. 1 to the Resolution of the Zabrze City Council No. XXII/284/08 of 17.03.2008.

${ }^{7}$ Zabrze City Development Strategy for the years 2008-2020 - published on the website of the Municipal Office at https://www.um.zabrze.pl, 8 August 2019.

${ }^{8}$ Report for the years 2015-2016 on the implementation of the City Development Strategy, p. 2 - publicshed on the BIP website at https://zabrze.magistrat.pl, August 8, 2019.

${ }^{9}$ From the introduction to the Report on the State of the City of Zabrze 2011, p. 3. Report published on the BIP website at https://zabrze.magistrat.pl, 8 August 2019.
} 
as municipal and real estate management were presented. The employment market, income of the inhabitants and the state of education were analysed. The activities of the health service, higher education and scientific institutions were presented. Public safety issues (including fire brigade, police, municipal police, municipal crisis management centre, prosecutor's office, courts) were also discussed. Information on cultural, sporting, recreational and other activities was made available. At the end, the financial figures related to the budget of Zabrze city were also shown.

Since 2019, all Polish municipalities have to obligatorily prepare similar reports. Nowadays, an additional tool for evaluating the level of implementation of the local government development strategy is the "Report on the state of the municipality" ${ }^{10}$, which is prepared every year and is subjected to a wide public debate. According to the Act, this document must include a summary of the activities of the executive body of the municipality in the previous year, and particularly "the implementation of policies, programmes and strategies, resolutions of the municipal council and the civil budget". Moreover, the municipal council may specify, by way of a resolution, detailed requirements for the report, the content of which is discussed during the discharge session. The Act also specifies that "the report is considered first (i.e. before the debate on granting the discharge - author's note)". In the debate, "councillors take the floor without time limits". There is also a legal possibility for residents to take the floor ${ }^{11}$. The result of the debate is a vote of confidence in the head of the commune or mayor of the city. The importance of this work, which is the report on the condition of the municipality, is confirmed by the provision that "if the executive body is not granted a vote of confidence in two consecutive years, the municipal council may adopt a resolution to hold a referendum on its appeal" ${ }^{12}$.

\subsection{The implementation of strategic objectives for social and economic revitalisation on the example of the city of Zabrze}

Similarly to the regional development plans being consistent with the directions of the country's development, the concepts developed with a view to transforming particular areas of urban life are to take into account the assumptions of the strategy adopted by the local government. The particular planning documents to be implemented must also certainly maintain complementarity. Hence, for example, when preparing the "Plan of Local

\footnotetext{
${ }^{10}$ After the amendment of the Act on Municipal Self-Government made in January 2018, the provisions of Article 28aa regarding the preparation of the report on the state of the municipality came into effect as of 2019.

${ }^{11}$ A resident who would like to take the floor in the debate on the municipal status report 'submits a written report to the chairman of the council, backed by signatures: (1) in a municipality with up to 20,000 inhabitants, at least 20 people; (2) in a municipality with more than 20,000 inhabitants, at least 50 people". Pursuant to point 7 of Article 28aa of the Act on Municipal Self-Government.

${ }^{12}$ According to point 10 art. 28 aa of the Act on Municipal Self-Government.
} 
Development of the City of Zabrze for the years 2005-2015"13, it was necessary to include: "The Study of Conditions and Directions of Spatial Development of the City of Zabrze"14, "Mining Municipality Activation Programme" ${ }^{15}$, "Environmental Protection Programme for the City of Zabrze"16, "Strategy for Solving Social Problems in the City of Zabrze"17 or even the "Waste Management Plan for the City of Zabrze"18.

The city development strategy is associated with planning documents specifying tasks, budget expenditures, the assumed schedule of activities and expected results in particular areas of functioning of a municipal government unit. This may apply to such areas as, for example, revitalisation. It is worth remembering that an important element in the development of a city - especially one that was integrally connected with the creation, expansion and then collapse of heavy industry - is revitalisation in its broadest sense. In its definition, according to the Polish law in force, it is "the process of bringing degraded areas out of crisis, conducted in a comprehensive manner, through integrated actions for the benefit of the local community, space and economy, territorially concentrated, executed by revitalisation stakeholders on the basis of a municipal revitalisation programme" ${ }^{19}$. The "Local Programme of Urban Revitalisation of the city of Zabrze for the years 2016-2023" is in operation in Zabrze ${ }^{20}$. The rehabilitation of degraded areas, restoration, renovation and modernisation of facilities, social revitalisation or economic restructuring are all interrelated. It should be emphasised that after the research conducted in the Katowice conurbation, "two types of crises were observed and described: a) standstill on the current path of development, which does not conform to contemporary trends and/or has lost its economic justification; this process can therefore be described as inertia, developmental drift; b) inability to create a new path of development due to cumulative, multidimensional (economic, social, spatial) shrinkage processes" (Gwosdz, Kwiatkowski et al., 2018, p. 132). The remedy may be to establish — first in the city development and industry strategies - innovative and ambitious goals, and then to pursue them consistently. Modern e-services may be an alternative to the declining heavy industry. However, using the potential of digital space is only possible if both relevant competences and access to proper tools become widespread. Therefore, municipal governments have joined in activities aimed at building the information society. In Zabrze, the structure of the adopted document: "e-Zabrze. The strategy of building the information society of the city of Zabrze until 2020+" was defined by researchers as a benchmark. By analysing its provisions,

\footnotetext{
${ }^{13}$ The Plan of Local Development of the City of Zabrze for the years 2005-2015 is published on the BIP website at https://zabrze.magistrat.pl, 10 August 2019.

14 The resolution of the Zabrze City Council of 22 November 1999.

15 The resolution of the Zabrze City Council of 13 December 1999.

${ }^{16}$ The resolution of the Zabrze City Council of 17 May 2004.

17 The resolution of the Zabrze City Council of 17 October 2002.

${ }^{18}$ The resolution of the Zabrze City Council of 17 May 2004.

${ }^{19}$ According to Article 2 of the Act on revitalisation of 9 October 2015 (Journal of Laws of 2015, item 1777).

${ }^{20}$ In its current version adopted by resolution No. LI/618/17 of the Zabrze City Council of 18 December 2017 on: amendment of resolution No. XXXV/372/16 of 19.12.2016 on the Local Revitalisation Programme of the Urban Areas of the City of Zabrze for the years 2016-2023.
} 
they formulated the conclusion that "the strategy is an important element of building the information society. Owing to it, individual municipalities, cities or voivodeships are given the possibilities of further rapid development. These activities should be conducted by a specially qualified and prepared team of analysts and trainers. Unfortunately, there is still little awareness of the problem in municipal government units" (Białkowski, Ł.W., Białkowski, W. et al., 2018, p. 20).

\section{The implementation of strategies that create new spheres of activity}

Another element of revitalisation transformations in post-industrial cities is giving new functions to decommissioned facilities belonging to the large economic organisations of the Polish People's Republic [PRL]. "The existence of areas with a high degree of degradation, where there is an accumulation of negative socio-economic and spatial conditions, constitutes a heavy burden on the development of the whole region. The reconstruction of active communities, which are partners for various urban institutions, is essential from the point of view of the interest of the community itself, as the generally understood quality of life is improving. It is also of supra-local importance, because 'bottom-up' development increases the chance of improving the competitiveness of the region due to the strength of social capital and the attractiveness of living space." (Rożałowska, 2018, p. 471). Zabrze is an example of a leader in the field of adapting the infrastructure of mining facilities to the needs of tourism. The historic Guido Coal Mine was opened to the public in mid-2007. The Zabrze tourist product was then joined by other tourist facilities such as: the Queen Louise Adit, which, after comprehensive revitalisation, comprises the excavations of the Queen Louise mine and the Main Key Hereditary Adit [Główna Kluczowa Sztolnia Dziedziczna], where underground cruises by barges in the restored canals, which used to float coal in the past, take place regularly. On 2 April 2013, the cultural institution of the City of Zabrze was established, co-managed by the local government of the Silesian Voivodeship, grouping the facilities of the industrial monuments route, i.e. the Coal Mining Museum, which has "a rich tourist and museum offer, focused primarily on discovering the mining heritage of the region. The route of the deepest hard coal mine in the world available for tourists is waiting for visitors, with many attractions related to both modern and historical mining"21. By mid-2019, the Industrial Monuments Route of Zabrze was visited by over a million tourists. It was on 21 May 2019 that the European Commission announced the winners of the Europa Nostra Award - a prestigious distinction in the field of cultural heritage in Europe. The prize was awarded to 25 winners from 16 countries. Among the winners was the mentioned facility from Poland, The Queen Louise

21 From the History of the Coal Mining Museum section of the official MGW website at https://www.muzeumgornictwa.pl, 10 August 2019. 
Adit. The President of Zabrze, Małgorzata Mańka-Szulik, commented at the time: "The Europa Nostra 2019 Award is a confirmation that the direction chosen in Zabrze for the revitalisation of industrial and technical monuments and the development of post-industrial tourism is appreciated both in Poland and abroad. Post-industrial heritage sites in Zabrze are known and appreciated by experts and tourists. Making the Queen Louise Adit Complex [Kompleks Sztolni Królowa Luiza] available to visitors is the result of conservation, construction and mining works being performed since 2009 for the amount of nearly PLN 200 million. The project has been financed from the budget of the city and the voivodeship, as well as EU funding and other external sources, such as: funds dedicated to environmental protection and ministerial grants"22. This opinion has been confirmed by scientists studying the adaptation of post-industrial facilities to new social and economic functions anticipated by urban development strategies. "One of the most successful examples of effective use of post-industrial heritage in Upper Silesia is the historic Zabrze Guido mine. The development of Zabrze as a city may not be as spectacular as the capital of the region (Katowice) and, at the same time, the first Metropolitan Association of Upper Silesia and Dąbrowa Basin in the country, but today it is Zabrze that has become the Polish capital of industrial tourism due to, among others, investments in the development of this very mine." (Smołka-Franke, 2018, pp. 485 and 486) Achieving such a position was precisely the strategic goal of priority P4. of the "Development Strategy of the city of Zabrze for the years 2008-2020" adopted in $2008^{23}$.

\section{Conclusion: Synergy to support growth}

The recommended development directions for post-industrial centres are focused on the achievement of objectives assuming a profound transformation of the economic structure, which are to promote innovation and entrepreneurship. What matters is the improvement of ecological conditions, development of modern infrastructure, as well as increased access to educational, medical, cultural, sports, recreation and other services. Generally, it can be concluded that — not only in the case of post-industrial areas — "the challenge for Poland is to implement the concept of smart cities, in particular in the context of the development and implementation of comprehensive (i.e. economic, social, environmental and spatial), innovative development initiatives" (Pichlak, 2018, p. 204). The establishment of conditions for the

\footnotetext{
${ }^{22}$ A statement by President Małgorzata Mańka-Szulik during the session of the City Council in Zabrze of 24 June 2019.

${ }^{23}$ Priority P4 "Metropolitan services" corresponding to the challenge "To achieve a desirable position in the Silesia Metropolis" for the strategic objective "C 16. Development of tourism based on post-industrial facilities". Source: Zabrze City Development Strategy for the years 2008-2020, p. 63.
} 
implementation of long-term development plans of post-industrial cities is the duty of central authorities $^{24}$, government administration at the voivodeship level, as well as local governments of the voivodeship, metropolis and land and magistrate districts. The strategies formulated at the local, regional and national levels should represent the standards adopted by the European Union. In this aspect, it is also worth remembering the EU document which replaced the "Lisbon Strategy", i.e. the "Europe 2020 Strategy". It includes "three interlinked priorities: (1) Smart growth: developing a knowledge and innovation-based economy; (2) Sustainable growth: promoting a more resource-efficient, greener and more competitive economy; (3) Inclusive growth: promoting a high-employment economy delivering social and territorial cohesion"25.

The post-industrial city can be resident-friendly, attractive in terms of investments and open to initiatives strengthening its potential. Nevertheless, the popular idea of building smart cities requires consistency and responsibility from the local government, because "local authorities, when making any decision concerning the functioning of the city, must take into consideration the implications of this decision for all spheres of the city's functioning - social, economic, spatial and environmental. Striving to achieve indicators that would allow one to define a given city as a smart city, local authorities should pursue a specific management policy, coordinating all the above-mentioned aspects" (Sikora-Fernandez, 2013, p. 93).

It is essential to have a coherent city development plan utilising the available resources. In the case of post-industrial areas, these are often facilities which require reorganisation of ownership issues and then time-consuming revitalisation and adaptation activities as part of a broader programme of economic, educational, cultural or tourist activation, which usually goes beyond a single building complex. This requires the local government to be aware of its role and apply for external financial resources to execute the prepared plans. The larger the municipal government entity, the easier it is to undertake professional activity aimed at effective fundraising, performance of a task and meeting its settlement procedures. Hence: "in many city offices with district rights, there are organisational entities acting as project management offices. Most often they are departments or offices, the name of which is related to European funds. The primary task of these entities is to plan projects and obtain

\footnotetext{
${ }^{24}$ An example of a dedicated project was the "Silesia 2.0" Industrial Support Programme for Silesia and Western Lesser Poland presented on 29 June 2015 by the Office of the Prime Minister and prepared as part of the work of the Interdepartmental Team for strengthening the industrial potential of Silesia and Western Lesser Poland. This project identified, among other things, regional potential, determining actions aimed at increasing competitiveness, developing investments, improving the state of the natural environment and pro-educational activities. It also included a concept of legislative standardisation of the existence of the metropolitan area, where it was stated: "according to the authors of the project, a metropolitan area with a degree of integration requiring a change in the administrative system and the creation of a metropolis is the Upper Silesian Agglomeration". Source: "Silesia 2.0", p. 84. The material was published at https://www.premier.gov.pl, 11 August 2019.

${ }^{25}$ Communication of the Commission - Europe 2020, A strategy for smart, sustainable and inclusive growth, Brussels 3 March 2010, p. 5. Source: https://ec.europa.eu, 7 August 2019.
} 
external funds for their execution" (Musioł-Urbańczyk, 2018, pp. 379, 380). In Zabrze, the Department of Project Execution is such an entity. It coordinates all activities regarding projects undertaken by the local government in interdepartmental cooperation if their funding comes from external sources. The scope of responsibilities of the department also includes "processing (preparing payment applications) projects financed from external sources, preparing reports and conducting evaluations of projects financed from external sources, cooperation or promotion of projects financed from external sources, preparing applications for financing from EU and national funds" ${ }^{26}$. The achievement of measurable results in the form of creation of a trail of restored technical monuments under the aegis of the local government helps private enterprises become involved in the programme. In the case of Zabrze, it can be mentioned that the Maciej Shaft, i.e. the "complex of objects of the former Concordia Mine" and later the "Pstrowski" Mine in Zabrze-Maciejów", is now accessible to tourists ${ }^{27}$. Another example is a historic Ty2-568 steam locomotive restored and kept on the premises of the international DB Cargo Group. This is how the synergy effect arises due to the activities of public and commercial entities, and "having identified development conditions resulting from the local or regional environment, investment project managers in small and medium enterprises may also include in them not only economic but also environmental and social effects" (Skowronek-Mielczarek, 2018, p. 20). Therefore, consistent implementation of the planning assumptions included in the strategies not only make the prepared programmes a reality, but also constitutes a driving force for further city development.

\section{References}

1. Angradi, T.R., Williams, K.C., Hoffman, J.C., Bolgrien, D.W. (2019). Goals, beneficiaries, and indicators of waterfront revitalization in Great Lakes Areas of Concern and coastal communities. Journal of Great Lakes Research, no. 45.

2. Beitel, K. (2016). Municipal Banking: An Overview. Financing Socially Just and Sustainable Forms of Urban Development. New York: Roosevelt Institute.

3. Białkowski, Ł.W., Białkowski, W., Jóźwiak, I.J. (2018). Strategia budowy społeczeństwa informacyjnego. Zeszyty Naukowe Politechniki Śląkiej. Organizacja i Zarządzanie, 130.

4. Caragliu, A., Del Bo, Ch., Nijkamp, P. (2008). Smart cities in Europe. Journal of Urban Technology, no. 2.

\footnotetext{
${ }^{26}$ Based on the characteristics of the Project Implementation Department published on the official website of the Municipal Office in Zabrze at https://www.um.zabrze.pl, 12 August 2019.

${ }^{27}$ The facility was renovated by DEMEX Ltd. [Sp. z o.o.], which transformed the shaft into a deep well, and the buildings, equipment and furnishings after the transformation now have completely new social, cultural and economic functions. Source: website of the Maciej Shaft complex at https://www.szybmaciej.pl, 12 August 2019.
} 
5. Chudzik, W. (2014). Zagadnienie Centralnego Okręgu Przemysłowego (1937-1939) w świetle poglądów politycznych. Annales Universitatis Mariae Curie-Skłodowska, sectio F-Historia, no. 69.

6. Cleland, D.I., Ireland, L.R. (2007). Project Management. Strategic Design and Implementation. McGraw-Hill Companies. New York.

7. Gwosdz, K., Kwiatkowski, T., Sobala-Gwosdz, A., Suchacka, M. (2018). Trajektorie rozwoju społeczno-ekonomicznego w poprzemysłowym obszarze metropolitalnym. Górnośląskie Studia Socjologiczne. Seria Nowa, z. 2.

8. Kaplan, S., Garret, K. (2005). The Use of Logic Models by Community Based Initiatives. Evaluation and Program Planning, $n r 28$.

9. Kołodko, G. (2019). Uwarunkowania i długookresowe implikacje Strategii dla Polski. Gospodarka Narodowa, $n r 2$.

10. Leśkiewicz, Z., Sienicka, I. (1982). Niektóre uwarunkowania załamań gospodarczych Polski. Ruch Prawniczy, Ekonomiczny i Socjologiczny, nr 4.

11. McCann, Ph. (2013). Modern Urban and Regional Economics. Oxford University Press.

12. Musioł-Urbańczyk, A. (2018). Biuro zarzadzania projektami w urzędach miast na prawach powiatu. Zeszyty Naukowe Politechniki Śląskiej. Organizacja i Zarządzanie, nr 121.

13. Pichlak, M. (2018). Inteligentne miasta w Polsce - rzeczywistość czy utopia? Zeszyty Naukowe Politechniki Śląskiej. Organizacja i Zarządzanie, nr 127.

14. Potkański, T. (2016). Zarzadzanie strategiczne na rzecz rozwoju w jednostkach samorządu terytorialnego. In: C. Trutkowski (ed.), Realizacja ustug publicznych w jednostkach samorzadu terytorialnego - ograniczenia, możliwości, rekomendacje. Warszawa: Fundacja Rozwoju Demokracji Lokalnej.

15. Prusek, A. (2019), Nowa pokryzysowa polityka rozwoju zrównoważonego a polska Strategia Odpowiedzialnego Rozwoju. Nierówności Społeczne a Wzrost Gospodarczy, nr 57.

16. Richards, G., Wilson, J. (2004). The Impact of Cultural Events on City Image: Rotterdam, Cultural Capital of Europe 2001. Urban Studies, $n r 41$.

17. Rodrik, D. (2014). Green Industrial Policy. Oxford Review of Economic Policy, $n r 3$.

18. Rożałowska, B. (2018). Idea partnerstwa w procesie rewitalizacji górniczych osiedli mieszkaniowych - szanse i dylematy. Zeszyty Naukowe Politechniki Śląskiej. Organizacja i Zarządzanie, $n r 129$.

19. Siekierski, J. (2013). Strategie rozwoju Polski w latach 1990-2030. Zeszyty Naukowe Małopolskiej Wyższej Szkoty Ekonomicznej w Tarnowie, nr 1.

20. Sikora-Fernandez, D. (2013). Koncepcja „,smart city” w założeniach polityki rozwoju miasta - polska perspektywa. Acta Universitatis Lodziensis. Folia Oeconomica, nr 290. 
21. Skowronek-Mielczarek, A. (2018). Inwestycje małych i średnich przedsiębiorstw w warunkach zrównoważonego rozwoju. Zeszyty Naukowe PWSZ w Płocku. Nauki Ekonomiczne, $n r$ 27, p. 20.

22. Smołka-Franke, B. (2018). Waloryzacja przestrzeni kulturowej miasta przemysłowego. Zeszyty Naukowe Politechniki Śląskiej. Organizacja i Zarządzanie, nr 123. 